\title{
JURNAL MEDIA HUKUM MEDIA
}

Vol. 27, No. 2, December 2020

P-ISSN: 0854-8919, E-ISSN: 2503-1023

Nationally Accredited Journal, Decree of MoHE No. 148/M/KPT/2020.

\section{The Challenges of Shariah Penal Code and Legal Pluralism in Aceh}

\author{
Muhammad Razi ${ }^{1}$, Khairil Azmin Mokhtar ${ }^{2}$ \\ Ahmad Ibrahim Kulliyyah of Laws, International Islamic University Malaysia, Malaysia \\ E-mail: razi.md@live.iium.edu.my \\ ka_mokhtar@iium.edu.my
}

\begin{tabular}{l} 
ARTICLE INFO \\
\hline Keywords: \\
legal system; legal \\
pluralism; syariah; qanun \\
jinayah; Indonesian legal \\
system \\
How to cite: \\
Razi, M. E Mokhtar, K. A. \\
(2020). The Challenges of \\
Shariah Penal Code and \\
Legal Pluralism in Aceh. \\
Jurnal Media Hukum, \\
27(2), 184-205 \\
Article History: \\
Received: 16-11-2020 \\
Reviewed: 22-11-2020 \\
Revised: 05-12-2020 \\
Accepted: 31-12-2020
\end{tabular}

\begin{abstract}
An outstanding feature of Aceh Special Region is its autonomy relating to the administration of Islamic Criminal justice system. Undoubtedly this power is one of the key features of the devolution of power to the region. It is a tedious process with numerous challenges and obstacles. The research paper aims to examine whether the prolonged development pertaining to the Islamic Criminal justice system's administration is due to the constitutional and administrative arrangements or actually lies in society. Devolution requires well-structured and systematic planning and execution. It involves various mechanisms and touches many issues. To blame the system for protracted progress is not something unexpected. However, the perception of the public or society of Aceh relating to the Shariah Criminal Justice System also has a significant impact. The research shows that despite the general manifestation of the local population's willingness and support for the system, some issues have emerged. The research reveals that the challenges and obstacles in prolonged development come from both the society and the system. Lack of understanding of the society towards Syariah Penal Code, problems faced by members of the People Representative Council (DPR) Aceh in drafting the Code, and the need to ensure strict compliance of the Code with Syariah are among obstacles faced. The issues and their effect on the implementation and enforcement of Aceh's Syariah Penal Code are scrutinized in the research paper. This is a qualitative study based on library and internet research. It is also legal research whereby the relevant laws are examined. The devolution in Aceh is more complicated than in other regions because it is coupled with "dualisme hukum" or legal pluralism within the Indonesian legal system.
\end{abstract}

\section{DOI: $10.18196 / j m h .20200151$}

Copyright (C) 2020 JURNAL MEDIA HUKUM. All rights reserved.

\section{Introduction}

Aceh is the foremost west part of the Republic of Indonesia granted special autonomy from the Central Government to govern and administer their governmental system. In all aspects of the Acehnese life, the existence of ethnic diversity and the 
implementation of Islamic religious principles have an influence on the legal system prevailing in Aceh. This is because the people of Aceh, which is regarded as Customary Law and Islamic Law, have an unwritten law that lives and is accepted. These two laws are the basis of Law that becomes the reference for the Acehnese people when it comes to settling conflicts that arise in society's midst (Ridha Maulana, 2019). It is evident by the issuance of Law No. 11 of 2006 about the Government of Aceh; a result of a peace settlement with the Free Aceh Movement. Before Aceh shifted some authorities, the Islamic criminal justice system does not fully accommodate as codified in Qanun Acara Jinayah Aceh, 2013. Therefore, the implementation of Islamic Law, including Islamic Criminal Law (Act 125), comprehensively is the special rights based on Law no. 44 of 1999 about establishing the particular province of Daerah Istimewa Aceh (now known by Aceh) 1 . Then this Law was revoked by the promulgation of Law No. 18 of 2001, considered the amendment of the previous Law. In the context of the unification of Law, the enactment of Islamic Law in Aceh gave rise to debate among the attorney. As a result, the implementation of Islamic Law in Aceh might see as an application of legal pluralism. ${ }^{2}$

An outstanding feature of Aceh Special Region is its autonomy relating to the Islamic Criminal justice system's administration. Undoubtedly this power is one of the key features of the devolution of power to the region. In relating to that, the validity of the implementation of Islamic Law in Aceh clearly been mentioned in several aspects of Laws, Qanun No. 5 of 2000 says as follows:

Article 5:

(1) To establish the privileges of Aceh concerning religious life, every person or legal entity domiciled in the district is obliged to uphold the implementation of Islamic Law in their lives.

(2) Implementation of Islamic Law as referred to in paragraph (1), includes: a. faith ('Aqidah); b. Worship (Ibadah); c. Civil Law (Mu'amalah); d. Morals (Akhlaq); e. Islamic education and preaching (amar ma'ruf nahi munkar); $f$. Treasury (Baitul Mal); g. Social Community; h. Islamic Syariah; i. Islamic defense; j. Justice System (Qadha); k. Islamic Criminal Law (Jinayat); l. Family Law (Munakahat; and m. Mawaris).

In supporting and strengthening the above conditions, the central Government promulgated Law No. 18 of 2001 regarding Special Autonomy. The Law clearly states that giving wider opportunities to regulate and manage their affairs, including economic resources, exploring natural resources and human resources, and applying Islamic Law in social life. The opportunity to regulate and organize the legal activity with Islamic Law as its spirits and values are based on a strong legal basis. Therefore, it can be stated that the implementation of Islamic Law in Aceh is a mandate of the Law. ${ }^{3}$

In addition, terms the implementation of Islamic Law or Islamic Criminal Code within the regional Aceh is strongly accommodated by the issuance of Law No. 11 of 2006

\footnotetext{
${ }^{1}$ It is based on Aceh's Governor Regulation No. 46 of 2009 concerning the use of Aceh name and the official title for the government in the official texts within the territorial Government of Aceh ("Pergub Aceh 46/2009"), the term "Nanggroe Aceh Darussalam" was changed to "Aceh".

2 Bahiej, A. (2014). Studi Komparatif terhadap Qanun Aceh tentang Hukum Jinayat dan Enakmen Jenayah Syariah Selangor Malaysia. Asy-Syir'ah, 48(2): 333-361.

3 Abubakar, A-Y. \& Marahalim. (2006). Hukum Pidana Islam di Provinsi Nanggroe Aceh Darussalam. Banda Aceh: Dinas Syari'at Islam, p. 5.
} 
about the Government of Aceh. The dynamics of Islamic Law, including the Islamic Criminal Code in the Acehnese community, faced various problems of legal dualism, including customary Law besides Indonesia criminal code (KUHP). For example, a person who commits a criminal offense will be sentenced by the community in the way of throwing and dying into a ditch. Indeed, punishment should only be the right of the state to implement; otherwise, chaos will occur (Ridwan, 2018).

The research paper aims to examine whether the prolonged development pertaining to the Islamic Criminal justice system's administration is due to the constitutional and administrative arrangements or actually lies in society. Devolution requires wellstructured and systematic planning and execution. It involves various mechanisms and touches many issues. To put the blame on the system for protracted progress is not something unexpected. However, the perception of the public or society of Aceh relating to the Shariah Criminal Justice System also has a significant impact. The research shows that despite the general manifestation of willingness and support of the local population for the system, some issues have emerged.

\section{Method}

This paper is qualitative research that adopted the library and internet methods. Also, this is legal research by an analytical approach. An analytical approach is a careful examination, evaluation, identification, and interpretation of data already existing in documents and articles. The researcher has analyzed the relevant legal provisions of Islamic Criminal law in Aceh and the constitutional and administrative arrangements about the criminal justice system. Additionally, it is necessary to describe the opinion of local population in Aceh special region where the prolonged development pertaining to the administration of Islamic Criminal justice system is concerned.

\section{Analysis and Results}

\subsection{Devolution's Effect on Islamic Criminal Code}

Devolution throughout of the broadly regional autonomous program granted to Aceh is a main factor having the more significant right than other provinces within the Republic of Indonesia. It was ranging when the Helsinki Agreement was announced in January 2005 that representatives of both side, Indonesian Government and the Free Aceh Movement (GAM) ${ }^{4}$ were resuming peace talks. Most commentators were pessimistic at the time ${ }^{5}$. Moreover, to relate to the Aceh special autonomy, the Agreement requires the Central Government to regulate special Law concerning the Aceh government, called UUPA (Law of Aceh Governing). The need for such provision due to settlement-agreement clearly stated in its introductory as follow:

\footnotetext{
4 The Free Aceh Movement, or GAM, is foremost established by Tengku Muhammad Hasan di Tiro on 4 December of 1976 as an educational and peace organization that is legally both International and Aceh Law (Teunku Hasan, 1985). Then, the organization is considered as the representative of the people of Aceh, whose goal is to separate Aceh from the Unitary State of the Republic of Indonesia because the rights of the people of Aceh are not fulfilled properly by the Government of Indonesia. Consequently, GAM was officially eliminated since the peace-building agreement achieved on 15 August of 2005 in Helsinki, Finland.

${ }^{5}$ Aspinall, E. (2005). The Helsinki Agreement: A more promising basis for peace in Aceh? Washington: East-West Center Washington, p.1
} 
The Government of Indonesia (GoI) and the Free Aceh Movement (GAM) confirm their commitment to a peaceful, comprehensive, and sustainable solution to the conflict in Aceh with dignity for all. The parties commit themselves to create conditions within which the Government of the Acehnese people can be manifested through a fair and democratic process within the unitary state and constitution of the Republic of Indonesia. The parties are deeply convinced that only the peaceful settlement of the conflict will enable the rebuilding of Aceh after the tsunami disaster on 26 December 2004 to progress and succeed. The parties to the conflict commit themselves to build mutual confidence and trust. This Memorandum of Understanding (MoU) details the agreement and the principles that will guide the transformation process.

Starting from the above points, based on the DPR members' approval, this Law gets to pass on 1 August of 2006, known as Law No.11 of 2006 concerning the Government of Aceh. Then, this Law contains 40 chapters, 273 articles, which are divided into several sections. The rules relating directly to the implementation of Islamic Law in Aceh are contained in Chapter XVII about the Implementation of Islamic Sharia, Chapter XVIII about the Shari'iyyah Court, and Chapter XIX about the Ulema Consultative Assembly (MPU). ${ }^{6}$

Furthermore, here will be mentioned sources or basis related to the issuance of Islamic Criminal Law in Aceh based on Law No. 11 of 2006 as follows:

Article 125:

(1) Islamic Law which implemented in Aceh include 'Aqidah, Syar'iyah and Akhlaq.

(2) Islamic Law as referred to in paragraph (1) includes Ibadah (worship), Ahwal al-syakhshiyah (family law), muamalah (civil Law), jinayah (Islamic criminal Law), qadha '(justice), tarbiyah (education), da'wah, syiar, and defense of Islam.

(3) Further provisions on the implementation of Islamic Law as intended in paragraph (1) shall be regulated by Aceh Qanun.

Therefore, from the various efforts and endeavors made by the Aceh government together with intellectuals and social organizations, two laws related directly to Islamic criminal Law in force in Aceh is promulgated; namely, Qanun of Aceh No. 6 of 2014 about the Islamic Criminal Law (Jinayah) and Qanun of Aceh No. 7 of 2013 about the Islamic criminal Procedural Law (Hukum Acara Jinayah). In supporting that the two qanuns come from devolution and or through the MoU Helsinki Agreement, it can be found in both considerations (point b). It mentions;

"That within the framework of implementing the Memorandum of Understanding between the Government of the Republic of Indonesia and the Free Aceh Movement (Memorandum of understanding between the Government of the Republic of Indonesia and the Free Aceh Movement, Helsinki 15 August 2005), the Government of the Republic of Indonesia and the

\footnotetext{
${ }^{6}$ Abubakar, A-Y. (2019). Syariat Islam di Aceh: Sebagai Keistimewaan dan Otonomi asimetris; Telaah Konsep dan Kewenangan. (Islamic Law in Aceh: As a Special and Asymmetrical Autonomy; An Authoritative and Conceptual Approaches) ed. By Ridwan Nurdin, Aceh: Sahifah.
} 
Free Aceh Movement affirmed their commitment to resolve the Aceh conflict in a peaceful, comprehensive, sustainable and dignified manner for all, and the parties are determined to create conditions so that the Government of the People of Aceh can be realized through a democratic and fair process within the Unitary State of the Republic of Indonesia" (Qanun of Aceh No. 6 of 2014 and No. 7 of 2013).

In line with that, the Law explains Islamic Criminal Law (Jinayah) as a part of Islamic Law. It is clearly stated in the next point (d) of the considerations that "based on the mandate of Article 125 of Law Number 11 of 2006 concerning the Government of Aceh, Jinayat Law (Criminal law) is part of Islamic Sharia implemented in Aceh". Therefore, devolution (regional autonomy) provides change and opportunity for the Government of Aceh to regulate and apply Islamic criminal Law principles in Aceh with some adjustments into the National Law. Of course, It will be more challenging.

\subsection{Legal Pluralism in Aceh}

The Article 18B paragraph (1) of the 1945 Constitution, which were later strengthened by Law Number 44 of 1999 concerning the Implementation of the Privileges of the Aceh Regional Province, and finally the emergence of Law Number 11 of 2006 concerning Aceh Government (UUPA) established a new legal system. In other words, apart from the application of the state law system, de facto in Aceh also applies the traditional Law and Islamic Law. ${ }^{7}$ Briefly, pluralism of the legal system that emerges in Aceh gets legal force and recognition from the Indonesian Government with Law Number 11 of 2006. Besides the enactment of the national legal system, Aceh also applies two other legal systems: Customary Law and Islamic Law.

\subsubsection{Qanun}

Qanun is a set of orders that govern life aspects for the Acehnese, whether in terms of governmental system, the implementation of Islamic Law, and customs or cultures. There are two types of Qanun can be found in Aceh; firstly, Qanun of Aceh at the province level called by Qanun Aceh, which means statutory provisions that are similar to provincial or regional regulations within Indonesia, ruling the administration of government and the life of the people of Aceh. Secondly, qanun of Aceh at the district level called by Qanun Kabupaten/Kota, which means statutory provisions that are similar to district/city rules, governing the administration of Government and the life of the people of Aceh at district level (Law No.11 of 2006, Article 1).

In conjunction with the theory of legal dualism or legal pluralism, it is clear by saying that the jurisdiction of the enforcement of Islamic Law as a positive law for the Aceh Government is officially distributed. In doing so, the Aceh Government must be adjusting to the rule of Law within the existing legal system in the Republic of Indonesia. Therefore, the Province of Aceh based on Law Number 11 of 2006 achieves an excellent opportunity to enact and enforce Islamic Law for the Muslims and Acehnese who are non-Muslim but subject themselves to Islamic Law voluntarily. In supporting that, the Qanun of Aceh No. 6 of 2014 about Islamic criminal Law, article (5), point (b) is clearly mentioned that the qanun shall be imposed to "Every non-

\footnotetext{
7 Maulana, R.(2019). Sistem Hukum Di Aceh Dan Kaitannya Dengan Pluralisme Hukum. Jurnal Geuthëë: Penelitian Multidisiplin, 2(3): 323-331.
} 
Muslim who commits Jarimah (crimes) in Aceh together with Muslims and chooses and subjects themselves voluntarily to the Jinayat Code (Islamic criminal code)".

Additionally, the legal pluralism in Aceh might be highlighted in the point (c) in the same Article. It mentions that the Law shall be enforced to "every non-Muslim who commits Jarimah in Aceh that is not regulated in the Criminal Code (KUHP) or the other criminal provisions, but it is regulated in this Qanun. Briefly, the provisions prescribed by the Qanun of Aceh indicate that besides the Acehnese people are subject to Islamic Law (Muslim), they can also be imposed under two different sources of Law (non-Muslim), KUHP and the Qanun of Aceh. Even though their status is different, Muslim and Non-Muslim. Therefore, the submission of these rules must be said as voluntary enforcement, so it should not force to be subjected to one of the laws, whether Qanun Jinayah or KUHP. In other words, the perpetrators who are not Muslim in Aceh are free to choose between KUHP and Qanun Jinayah for his criminal offence.

Furthermore, besides Islamic Law, which became a reference in deciding a case that occurred in Aceh, customary Law is also considered a source of laws concerning Acehnese society's customs. It can be proven by the birth of Aceh Qanun No. 9 of 2008 about the Development of customary life and customs. There is mentioned that "Customary Law is a set of unwritten provisions that live and develop in Acehnese society, which have sanctions if violated" (Qanun of Aceh No. 9 of 2008, Article 1).

\subsubsection{KUHP/Kitab Undang-Undang Hukum Pidana (Criminal Code)}

Wirjono Projowikoro (1985) gives an understanding of the meaning of pidana. Pidana, accordingly, is the thing that is delegated by the ruling agency over a person as something he does not feel comfortable with and things that do not distribute every day. He then defined criminal Law with a concise understanding that is a set of rules concerning pidana (criminal acts). So, KUHP/the Criminal Code is a statutory regulation that sets material criminal acts in Indonesia. Furthermore, this Code is a Dutch colonial legacy (Wetboek van Strafrecht voor Nederlands-Indië) that is enforced through the principle of concordat and passed through Law number 1 of 1946 and was enforced publicly through Law number 73 of $1958 .{ }^{8}$

Likely other provinces in Indonesia, Aceh also adopts the rules written in the Criminal Code (KUHP), even though the enforcement goes to perpetrators of crimes that are not Muslim. While the criminals who are Muslim must subject to the Qanun Jinayah of Aceh as stipulated in the Qanun Jinayah No. 6 of 2014. Then, it must also be known that the birth of the Qanun Jinayah of Aceh is due to the incomplete Law of the Criminal Procedure Code / KUHAP or not fully can meet the needs of Qanun Jinayah enforcement in Aceh. ${ }^{9}$ The Law consists of three books. Book I contains general provisions (Algemene Leerstukken), which are provisions for all criminal acts (acts for which the perpetrator is subject to criminal penalties, strafbare feiten). Book II explains

\footnotetext{
8 Ulfah, E. N. (2016). Urgensi Pembaruan Kitab Undang-Undang Hukum Pidana: Analisis Kajian Perkara Nomor 46/PUU-XIV/2016. IJCLS (Indonesian Journal of Criminal Law Studies), 1(1): 72-86.

${ }^{9}$ In considerations of Qanun Aceh No. 7 of 2013 about the Procedural Islamic Criminal Law, clearly mentions that "the existing rules in the Criminal Procedure Code (KUHAP) have not entirely been able to cover the needs of Qanun jinayat enforcement in Aceh".
} 
criminal actions, which are called misdrijven or crime, while Book III contains criminal acts that are called overtredingen or violations. ${ }^{10}$

Based on the above explanation, it highlights that a legal principle in the Indonesian context, the application of Criminal Law by the applicable laws and procedures, not only embraces Positive Law (KUHP) but also applies customary Law and Islamic Criminal Law (Jinayah) as it applies in Aceh. In other words, Criminal Law, which applies based on Indonesian laws and regulations, derives from three criminal law systems, namely positive criminal Law (KUHP), Customary Law, and Islamic Criminal Law. ${ }^{11}$

\subsection{Islamic Criminal Justice System in Aceh}

Generally, Criminal Justice System (CJS) is the mechanism of action in overwhelming crimes involving several agencies such as the police, prosecutors, courts, and correctional institutions (Lembaga Pemasyarakatan) the system. In the same sense, CJS is "the system of law enforcement that is directly involved in apprehending, prosecuting, defending, sentencing, and punishing those who are suspected or convicted of criminal offenses. ${ }^{12}$ In short, the Criminal Justice System (CJS) is defined as "Agencies and institutions directly involved in the implementation of public policy concerning crime, mainly the law enforcement agencies, court, and correction". Though the police, courts, correction institutions are separate governmental institutions, they are tied together because of the necessity to interact. ${ }^{13}$

Based on the above definition, if it relates to the criminal justice system in Islam, generally, it is not much different from the theory of CJS in terms of the process. However, in Islam, it must be in line with the provisions that originated from the Qur'an and Hadith as the primary source. Additionally, Bassiouni. M (1982) clearly states in his book "The Islamic Criminal Justice System" that:

In the procedural area, Muslim states have adopted the western model with different variations in which judicial administration is not much different from the system and practice of most countries who follow that model whether they now be western European or Socialist European or Asian States. ${ }^{14}$

Therefore, in countries that apply Islamic criminal Law, in term of the process or administration of applying criminal Law against to perpetrator, there are still several bodies or agencies are involved in achieving the principles of the implementation of the Law, whether the police, prosecutors, Court, and correctional institutions. In conjunction to the regulations, at least there are nine principles of the implementation of Islamic criminal Law as stated by Safrijal (2017) in his book "Hukum Pidana

\footnotetext{
10 Projowikoro, W. (1986). Asas-asas Hukum Pidana di Indonesia. Edisi ke-2 dari Cet. Ke-4, Bandung: PT. Eresco Bandung, p. 4.

11 Safrijal, A. (2017). Hukum Pidana Islam/Jinayat Dan Pelaksanaannya Di Aceh (Islamic Criminal Law/Jinayat and Its Implementation in Aceh). 1st ed. Banda Aceh: FH UNMUHA, p. 29.

12 Lexico Dictionary, accessed at https://www.lexico.com/definition/criminal_justice_system on 20 February of 2020.

13 David W. N. (1999). America's Courts and the Criminal Justice System. 6th ed, The United States of America: Wadsworth Publishing Company, p. 3.

14 Bassiouni, M. C. (1982). Sources of Islamic Law, and The Protection of Human Rights in The Islamic Criminal Justice System in The Islamic criminal justice system. Ed. Bassiouni, M. The United States of America: Oceana Publications, Inc, p. 41.
} 
Islam/Jinayat dan Pelaksanaanya di Aceh (Islamic Criminal Law/Jinayat and Its Implementation in Aceh). Theses include the basis of legality, the basis of lawlessness, the basis of legal certainty, the basis of personality, the basis of innocent thought (praduga tak bersalah), the basis of virtue, the principle of justice, the basis of peace, and the basis of deliberation/consultation (musyawarah). Yet, there is the co-related basis of the implementation Jinayah code in Aceh as stated in Qanun of Aceh No 6 of 2014, that is legitimacy (Islam), legality, justice and balance, protection of human rights, and education to the community (tadabbur) (Act. 2).

Additionally, Law No. 44 of 1999, Law No 18 of 2001, and Law No. 6 of 2006 provide privileges to the province of Aceh and give rise to a new nuance in the development of Law in Indonesia. Even though Indonesia's largely-secular laws apply in Aceh, the Aceh government passed additional provisions, and some derived from Islamic criminal Law after Indonesia authorized its provinces to enact regional regulations (perda) and granted Aceh special autonomy to implement Islamic Law for the Acehnese. Aceh government has the authority to administer the procedural enforcement of Islamic Criminal Law in Aceh.

The procedural arrangements of Syari'ah penal code (Islamic Criminal Justice System) in Aceh, clearly stipulated in Law No. 11 of 2006, Chapter XVII about Mahkamah Syar'iyyah (Islamic Court), Chapter XXVI about the Police, and Chapter XXVII about Prosecutor. Moreover, to classify into the elements or components of the CJS in general, it can be highlighted that; Law enforcement agencies included the Police, Wilayatul Hisbah (Syari'ah Police), the prosecutor; Court included Mahkamah Syar'iyyah, and Correction included prison or Lembaga Pemasyarakatan (LP).

\subsubsection{Law Enforcement}

Law enforcement is described as the main component in CJS theory in which there are several agencies at the central, regional, city, and even smaller levels. They formed and aimed to prevent criminal behavior, to reduce crime, to apprehend and arrest offenders, to protect life and property, and to regulate noncriminal conduct (Robert, 1991). ${ }^{15}$ In the context of Aceh, the law enforcement as mentioned above is under the authority of the Police, Wliyataul Hisbah (WH) and the Prosecutor.

Police is national Police of the Republic of Indonesia serving or on duty in Aceh. Then, the Republic of Indonesia's National Police Official (Pejabat Kepolisian Negara Republik Indonesia), referred to as the National Police Officer (Pejabat Polri), is a member of the Indonesian National Police. In support to that, the authorities and duties of the Police officer that served in Aceh are highlighted in Law No. 6 of 2006 as follows;

Article 204:

(1) The Police Force in Aceh is part of the Indonesian National Police.

(2) The Police in Aceh are assigned to maintain the security and order of the community, enforcing the Law, protecting, preserving, serving the community, and carrying out other tasks given by the Law.

(3) The Aceh Police Chief coordinates the Governor relating to peace and order policies in the community in Aceh.

(4) The carrying out of police duties in terms of peace and order, as referred to in paragraph (3), shall be held responsible by the Head of Aceh Police to the Governor.

15 Pursley, R. D. (1991). Introduction to Criminal Justice, 5th ed. The United States of America: Macmillan Publishing Company, p. 6-11. 
(5) The Head of the Aceh Police Force is responsible to the Head of the Indonesian National Police for the development of the police force in Aceh within the framework of carrying out the duties of the Indonesian National Police.

Then, the duties and authority of the Police in the Criminal Justice System in Ace was stated in Qanun of Aceh No. 7 of 2013 concerning Islamic Criminal Procedural Law (QAJ), namely as detectives and investigators.

Article 6:

"Detectives are Polri (National Police) and PPNS officials (Civil Servant Investigation Officer) who have been authorized by the Law and/or Qanun to conduct an investigation."

Article 7:

(1) The detectives, as referred to in Article 6, as the obligation authorized:

a. To receive reports or complaints from someone about the occurrence of crimes;

b. To seek information and evidence;

c. To charge someone to stop being suspected and ask questions and check personal identification; and

d. To take other actions responsibly based on Law and in line with principles of Islamic Law.

(2) The Detectives, as referred to in Article 6, by command of the investigator, shall take action:

a. arrestment, the prohibition of leaving premises, inspect and seizing;

$b$. investigation and seizure of the letter;

c. taking fingerprints and photo of someone, and/or

d. brings and confront someone (suspected) to the investigator.

(3) The Detectives prepares and submits a report on the results of the procedures referred to in paragraph (1) and paragraph (2) to the Investigator.

The above-mentioned Article provides a brief authoritative duty for the Police as Detective agency in the Islamic criminal justice system in Aceh. Thus, it can be highlighted that the Police authorized to as follows; to receive reports or complaints about crimes, to look for and collect evidence either to prove someone is doing guilty. Furthermore, the National Police authorized as investigator is mentioned in the next Act, as follows:

Article 8:

(1) Investigators consist of:

a. National Police Officer; and

b. The particular PPNS that given specific authority by Law and/or Qanun.

Article 9:

(1) The National Police Investigator as referred to in Article 8 paragraph (1) letter

(a) as his obligation is authorized:

a. To receive a report or complaint from a person or detective concerning the occurrence of crimes;

b. To take the first action at the time of the scene;

c. To ask to stop a suspect and check the identity of the suspect;

d. To arrest, detain, investigate, and seizure; 
e. To scrutinize and confiscate letters;

f. To take fingerprints and photo of a suspect;

g. To call people to be heard and examined as a suspect or witness;

$h$. To ask for expert information when needed in dealing with the investigation of the case;

i. To stop the investigation;

j. To receive a copy of the case file from PPNS;

$k$. To take other actions according to the Law that is responsible and appropriate with the principles of Islamic Law.

Accordingly, the Police's official duties as the investigator agency stipulated in the Act (8) and (9) imply the police's overlapping duties as detective and the police as investigator. In other words, the Police, either as detective or investigator are possibly dealt with the same duties, such as receiving reports or complaints, arrest suspects, investigating, and so on. However, one of the police's duties that differentiate both of them is the stopping investigation right for the investigator, not for the detective. Likewise, PPNS has some duties in the process of the successful implementation of Islamic Criminal Law in Aceh. Some of them had been stated in the Act (9) point (2) are some of the duties of the Police. For instance, to bring the expert witnesses when needed in dealing with the investigation; to make a Commencement of Investigation/Surat Perintah Dimulainya Penyidikan (SPDP) to the Public Prosecutor, and others.

While, prosecutor is a functional officer who is authorized by Law to serve as a public prosecutor and executor of a court verdict that has obtained permanent legal force and other authorities based on the Law and Qanun (Qanun of Aceh N0. 7 of 2013). Moreover, Law No 11 of 2006 prescribes that the member of prosecutors are; (1) The Attorney General's Office in Aceh is part of the Attorney General's Office of the Republic of Indonesia and (2) The Attorney General's Office in Aceh carries out its duties and technical policies in the field of law enforcement including the implementation of Islamic sharia. Among the authorities given to Prosecutor is mentioned in the Qanun, those are:

Article 15:

Authorized Public Prosecutor:

a. To receive and examine the investigation file or documents from the Investigator or Assistant Investigator;

b. To conduct pre-prosecution if there are deficiencies relating to the investigation, by giving instructions due to the completing investigation steps for Investigator based on the Laws and Regulations;

c. To provide an extension of detention, carry out an arrest or further detention and/or change the status of additional detainees and/or change the status of detainees after the Investigator has delegated the case;

d. making indictment;

e. To transfer cases to the Court;

f. To deliver a notification to the Defendant and Witness about the procurements of the day and time of the case are set up, accompanied by an indictment to come on a predetermined trial;

g. To prosecute; 
h. To carry out other actions within the scope of duties and responsibilities as public prosecutor according to the provisions of this Qanun and/or other Provision, and;

i. To carry out the judgment and decision of the judges.

Based on the above legal provisions and rules, the public Prosecutor has obtained a brief and legal authority to act as a prosecutor for criminal cases that occur in his area. Furthermore, these duties and authorities carried out must be in accordance with the guidance of the Qanun and the Law in Aceh.

\subsubsection{Court}

The courts are consisting of all judicial agencies at all levels of Government in the administration of CJS. These are formed and aimed to protect the rights of the accused, determine by all available legal means whether a person is legally guilty of a crime, settle appropriately of those convicted of crimes, protect society, and prevent and reduce criminal behavior. ${ }^{16}$ As an autonomous region, it is necessary to underline that the Aceh Islamic Court (Mahkamah Syar'iyyah Aceh) and the district/city Islamic Court are the courts' executing authority judiciary in the religious court setting, which is a part of the national justice system. ${ }^{17}$ However, Mahkamah Sya'riyyah of Aceh has transferred the authority to carry out its functions free from any party's interference out of the Court. It is necessary to bring the dictates of the authorized Islamic courts in Aceh based on Law No. 11 of 2006, as follows:

Article 128:

(1) Islamic Shari'ah justice in Aceh is part of the national justice system within the religious court setting conducted by the Shariah Court that is free from the interference of any party.

(2) The Shariah Court is a court for anyone who is a Muslim and domiciled in Aceh.

(3) The Syar'iyah Court has the authority to examine, hear, decide, and settle cases covering the areas of ahwal al-syakhsiyah (family law), muamalah (civil Law), and jinayah (criminal Law) based on Islamic shari'ah.

(4) The Aceh Qanun regulates further provisions regarding the fields of ahwal al-syakhsiyah (family law), muamalah (civil Law), and jinayah (criminal Law) as referred to in paragraph (3).

Article 129:

(1) In the criminal cases committed by two or more people jointly with nonMuslim, non-Muslim may choose and submit themselves voluntarily to the jinayah law.

(2) Every person who is not a Muslim commits a criminal act that is not regulated in the Criminal Law Code (KUHP) or criminal provisions outside KUHP, then subject to Jinayah Law.

(3) Aceh residents who commit acts outside of Aceh apply the Criminal Law Code.

16 Pursley, R. D. (1991). Introduction to Criminal Justice, 5th ed. The United States of America: Macmillan Publishing Company, p. 6-11.

17 Abubakar, A-Y. (2019). Syariat Islam di Aceh: Sebagai Keistimewaan dan Otonomi asimetris; Telaah Konsep dan Kewenangan. (Islamic Law in Aceh: As a Special and Asymmetrical Autonomy; An Authoritative and Conceptual Approaches) ed. By Ridwan Nurdin, Aceh: Sahifah. 
Article 130:

The Syar'iyah Court as referred to in Article 128 paragraph (1) consists of the district/city Syar'iyah Court as the first Court and the Aceh Syar'iyah Court as the Court of appeal.

Article 131:

(1) The verdict of the Mahkamah Syar'iyyah Aceh as referred to in Article 128 paragraph (1) shall appeal to the Supreme Court.

(2) The appealed case as referred to in paragraph (1) concerning marriage, talaq, divorce, and reconciliation (ruju') is settled by the Supreme Court not exceeding than 30 (thirty) days after being registered in the Registrar's Office of the Supreme Court.

(3) Regarding the verdict of the Mahkamah Sya'iyyah of Aceh or the Syar'iyah Court which has obtained permanent legal force, the related party may submit a review to the Supreme Court if there are certain things or conditions stipulated in Law.

(4) The judicial review as referred to in paragraph (3) concerning marriage, talaq, divorce, and reconciliation is settled no later than 30 (thirty) days after being registered at the Registrar's Office of the Supreme Court.

Article 132:

(1) The procedural Law applicable to Mahkamah Syar'iyyah is the procedural Law administered in the Qanun of Aceh.

(2) Before the Aceh Qanun concerning procedural Law in paragraph (1) was regulated:

a. The procedural Law that applies to Mahkamah Shar'iyyah as long as it is concerning the ahwal alsyakhsiyah (family law) and muamalah (civil Law) is the procedural Law as it applies to courts in the religious court setting except those regulated explicitly in this Law.

b. The procedural Law applicable to Mahkamah Syar'iyyah as long as it is related to jinayah is the procedural Law as it applies to courts in the general court setting except those regulated explicitly in this Law.

These laws are among provisions about Mahkamah Syar'iyyah as stipulated in Law No 11 of 2006 about Aceh Governance. However, at least 5 Articles in Chapter XVIII about Mahkahmah Syar'iyyah expressly set forth the procedural arrangements of the Islamic criminal justice system administered in the procedural rules. Additionally, Mahkamah Sya'iyyah referred to in legal provisions, was formed to examine, hear, decide, and settle cases dealing with Family Law, Civil Law, and Criminal Law. All rules, strictly speaking, must concern with Islamic values. ${ }^{18}$ In contrast, the legal provisions where the criminal cases are concerned with KUHP were not obliged to adjust to the Islamic sources or values. It is in line with the aims and functions of KUHP in Indonesia, which are generally formed to manage community life to accomplish and establish public orders.

Besides, the Shariah Court also adheres to three levels of justice, namely the first level, the level of appeal, and the level of cassation to the Supreme Court. After the

\footnotetext{
18 Abubakar, M, Suhaimi \& Basri. (2011). Kewenangan Pemerintah Aceh terhadap Pelaksanaan Fungsi Mahkamah Syar'iyah dalam Sistem Peradilan Nasional (Tinjauan tentang Kewenangan Yustisi dalam Otonomi Khusus). Kanun: Jurnal Ilmu Hukum, 3(1): 49-64, and see also Ernawati (2014).
} 
enactment of Law Number 11 of 2006, it highlighted that principally, the Syar'iyah Court's validity is the same as the Religious Courts. However, from the scope of the functional authority, the Syar'iyah Court's competency is much broader than what can administratively be carried out by the Religious Courts. It can be seen that the power of the Syar'iyah Court includes handling legal cases that touch the concept of Jinayah/Islamic Criminal Law. ${ }^{19}$ The criminal offense that proceed by the Court comprehends bigger part of crimes prescribed in Islamic Criminal Law except murder crimes. The criminal offense includes alcohol/khamar (consumption, production, and distribution); gambling (maisir); being alone with someone of the opposite sex who is not a spouse or a relative (khalwat); committing intimacy outside marriage (ikhtilath); adultery (zina); sexual harassment; rape; falsely accusing someone of adultery (qadzaf); homosexual (liwath); and lesbian acts (musahaqah). In short, the Mahkamah Syar'iyyah has broader powers than the Religious Courts, as said by Tim Lindsey and Cate Summer, who demonstrated that "Shari'ah in the Indonesian system of courts for Muslims is thus largely symbolic, at least as a formal source of Law. Except for Aceh (where its jurisdiction as the Mahkamah Syar'iyah is much wider), the Religious Courts jurisdiction is limited by statute to only a few aspects of Islamic legal tradition." .20

In relating to punishment, the Court has the authority to decide and impose whether hudud or ta'zir sentences against offender. ${ }^{21}$ However, as far as the research is concerned, it showed that in the Qanun of Aceh, there was no specific authority dealt with capital punishment (qishas) for murder offenses. Notwithstanding, if it relates to Islamic Criminal principles, qishas is one of the penalties that are regulated in the Qur'an and Hadith. ${ }^{22}$ If a region applies Islamic Law consistently, then crime, particularly murder, would decrease significantly or disappear. Furthermore, beheading (death penalty) is more in line with Islamic Law and will cause a deterrent effect, and strict punishment accomplished human beings' security. ${ }^{23}$

\subsubsection{Correction}

Generally, the corrections are directly or indirectly responsible upon executive agencies at all levels Government to maintain institutions, protect law-abiding members of society, reform offenders, and deter crimes. ${ }^{24}$ In the same sense, correction is defined as the agencies of justice in the Criminal Justice System that take custody of offenders after their conviction. They are entrusted with their treatment and control. ${ }^{25}$ Therefore, when a person committed a criminal offense, the provincial or central Government,

\footnotetext{
19 Ernawati. (2014). Kewenangan Mahkamah Syar'iyah Di Aceh Terhadap Hukum Jinayah Keterkaitan Hukum Materiil Dan Hukum Formil. Forum Ilmiah Indonusa, 11(3): 433-445.

20 Adhani, H. (2019). Menakar Konstitusionalitas Syari'at Islam dan Mahkamah Syar'iyah di Provinsi Aceh. Jurnal Konstitusi, 16(3): 606-629.At https:// doi.org/10.31078/jk1638.

${ }^{21}$ Hudud is the standard of punishments expressly prescribed and determined the style, and measurement of the sentences in the Qanun of Aceh. Whereas ta'zir defined as a penalty determined in the form of option, and it can imply the degree of the highest or lowest boundary (see, Qanun of Aceh No. 6 of 2014). 22 Safrijal, A. (2017). Hukum Pidana Islam/Jinayat Dan Pelaksanaannya Di Aceh (Islamic Criminal Law/Jinayat and Its Implementation in Aceh). 1st ed. Banda Aceh: FH UNMUHA, p. 29

23 Thegurdian. (2018). Idonesian province considers beheading as murder punishment | World news | The Guardian". Available online from: https://www.theguardian.com/world/2018/mar/14/indonesianprovince-aceh-considers-beheading-as-punishment. Aaccessed on 26 February, 2020 at 08:00 AM.

24 Pursley, R. D. (1991). Introduction to Criminal Justice, 5th ed. The United States of America: Macmillan Publishing Company, p. 6-11.

25 Senna, J. J. \& Siegel, L. J. (1999). Introduction to Criminal Justice. $8^{\text {th }}$ Edition, The United State of America: Wadsworth Publishing Company, p. 484.
} 
through their sentencing authority, have the right to convince him or her in a disciplinary place for an extended period. Moreover, corrective efforts are usually consisting of the entire range of treatment and punishment that included boot camps, jails, reformatories, and penal institutions/prisons (Senna \& Siegel). Then, in Indonesia, there are two correctional Institutions within the Indonesian Criminal Code System: Lembaga Pemasyarakatan/Correctional Institution (LAPAS) and Rumah Tahanan Negara/Jail (RUTAN). Additionally, both are running under the Ministry of Law and Human Rights (MENKUMHAM), but these two institutions have distinctive functions inapplicability. For instance, there are some different administrative functions that can be highlighted in the table 1.

\section{Correctional Institution (LAPAS)}

Jail (RUTAN)

The place where put as custody, supervise and educate Prisoners and Penitentiary proteges.

Inhabited by prisoners (narapidana) or convicts (terpidana) ${ }^{26}$

The time/duration of supervision is the duration through the process over punishment or sanctions.

Place in which the suspect/defendant is temporarily detained before the issuance of a judgment.

Those who inhabit the detention center are suspects or defendants

The time/period of detention is throughout the process of investigation, prosecution, and examination at a court hearing.

Table 1. The Different administrative functions LAPAS and RUTAN

Source: It was cited and modified by a researcher from www.hukumonline.com and Law No. 12 of 1995 and PP (Peraturan Pemerintah/government regulation) No. 55 of 1999.

However, the two Qanun of Aceh (Qanun No. 7 of 2013 and No. 6 of 2014) did not mention the efforts and steps to precisely guide convicted persons. However, to relate to the correctional institution, it can be deduced from Chapter XIX of Qanun No. 7 about the execution of the judgment of the Court. Article 248 states that if the offender has convicted with 'uqubat (punishments), a fine or imprisonment and then sentenced to a similar punishment before undertaking punishment that was decided earlier, then shall execute with the punishment imposed first, then together with second punishment. Hence, there has no specific regulation in the form of Qanun that has been issued to regulate the procedures for reforming a perpetrator who was convicted. However, occasionally, the matters do not stipulate in Qanun, and then it will be subjected to the provisions of the Law applies in Indonesia. In this case, the researcher feels that Aceh is also used Law No. 12 of 1995 in terms of custody, reforming, and educating the offender.

\subsection{The Opinions of the Acehnese}

The Acehnese people's discourse on the enactment of Islamic sharia is not something new and appears suddenly. Nevertheless, it is a piece of historical evidence that has

\footnotetext{
26 According to Law No. 12 of 1995 about the Communities (Pemasyarakatan), there is mentioned that the convicted person (terpidana) is a person convicted based on the decision of the court that has obtained permanent legal force. Whereas, the prisoner (narapidana) are criminals who sentenced and underwent punishments in the correctional institutions (LAPAS) and missing the current independence.
} 
proceeded along with the changing times and advances of the nation's civilization, especially the Aceh Community. Cicero (106-43 BC) related to this expressed as quoted by Abdul Gani Isa that "history is the witness that testifies to the passing of time; it illuminates reality, vitalizes memory, and provides daily guidance life, bring us tidings of antiquity". ${ }^{27}$ Hence, a general description of the Aceh's historical ties and the presence of Islam proved how Islamic Law had gained a unique and profound place in the Acehnese lives. In terms of religion, the Acehnese population is Muslim and is known by the people who are devoutly practicing Islamic sharia, upholding customs, and relatively fanatical. Furthermore, Andul Gani Isa added that there is undoubtedly the diversity of opinions about the formalization or legislation of Islamic Code (including Penal Code) in Aceh is remained among the Aceh community. According to him, the verity views of the Acehnese on the legislative process are influenced by three essential components, namely substance, structure, and legal culture.

Firstly, concerning the Acehnese's understanding of the legislation of Syari'ah in the context of the substance of the Law, it is still prolonged. For them, the critical thing is not only about legislation, but the essential is the Islamic sharia upright in the "Serambi Mekkah," and Syaria'h is not to be used by political interests. Hence, it conveys that Acehnese's perception towards the principles of Islamic Law implemented in Aceh is not fully covered. However, Al-Yasa'a, in a public dialogue, states that the formalization and application of Islamic Law in Aceh still raises a bias perception in the community in terms of interpretation. In some cases, it has progressed even though it cannot provide satisfaction for all components of society. ${ }^{28}$

Secondly, the legal structure in the sense of Indonesian Law is law enforcement institutions such as the police, prosecutors, and courts both the first level, the level of appeal, and the level of cassation. These institutions are an essential element and factor in dealing with the regulations or law enforcement, either the Rule of Law is running successfully or staying in places. Therefore, the lack of public trust over law enforcement institutions causes the institution's structure to be ineffective. Furthermore, Abdul Gani reveals that the crisis of public trust concerning law enforcement is influenced by four factors: the leaders lack understanding of Islamic Law, law enforcement is considered discriminatory, and lack muhtasib personnel (Syari'ah Police), and the performance of the apparatus is still weak. In short, When the community is no longer to believe in law enforcement officers, then the people's perception of Islamic Law, especially Criminal Law, is also not sufficient. When there is a member of a particularly related institution that violates the legal norms, it is not going in proceeding as usual as ordinary people.

Thirdly, legal culture refers to opinions, attitudes, values, and expectations concerning Law and legal institutions (Friedman, 1992 was quoted by Abdul Gani). ${ }^{29}$ Additionally, it is a collection of organically related customs to culture as a whole, such as norms of customs, moral customs, Law, including the religions and beliefs adopted by the

\footnotetext{
27 Isa, A. G. (2013). Formalisasi Syari'at Islam di Aceh; Pendekatan Adat, Budaya dan Hukum. Banda Aceh: Yayasan Pena, p. 276. 
community. Moreover, the different forms of legal culture that are embraced and become a habit in a society and country will significantly affect the practice towards the application of the Law. In a traditional society, it would be different from a society with an advanced and modern way of life. In traditional societies, respect for the Law is still high because necessitated by moral and religious values (beliefs) adopted. ${ }^{30}$ Therefore, Acehnese's traditions and culture were formed the uniqueness of legal development and how they interact with the Law, especially Islamic Law (Islamic penal Code).

\subsection{The Factors of Prolong development: Analysis}

In the historical development of Islamic Law, Islamic scholars' efforts still lack to endeavor an appropriate format of transformation and integration for Islamic Law into the legal system and political aspect within the modern country. Though, some of these are recorded by the ideas of Ibn al-Muqaffa '(720-760 AD), which advocates taqnin (legislative process) to the caliph Ja 'far al-Mansur and considers the first legislation of Islamic Law throughout history. ${ }^{31}$

The legislation process of the Islamic Criminal Code in Aceh, of course, necessitates a very long time since the Helsinki MoU was ratified for more than a decade. However, if it referred to the privileges of Aceh, the Islamic Criminal Code should be entirely enacted and implemented as a whole. In fact, the penal code was extracted from the primary sources; Al-Qur'an and Hadith, but it cannot be absorbed from there thoroughly. The stagnation mainly occurs in one of the essential elements in Islamic Criminal Law, namely murder offense, which consequently must be punished by qisas. Al-Qur'an and Hadis is expressively mentioned about the qisas sentence against whether the perpetrators intentional and planned murders, as Allah says which means:

"O ye who believe! the Law of equality is prescribed to you in cases of murder: the free for the free, the slave for the slave, the woman for the woman. But if any remission is made by the brother of the slain, then grant any reasonable demand, and compensate him with handsome gratitude, this is a concession and a Mercy from your Lord. After this whoever exceeds the limits shall be in grave penalty", (Surah Al-Baqarah:178).

Based on the stipulations mentioned in the Qur'an, it is evident that the punishment of qisas is a part of Islamic criminal sanctions since Islam emerged 14 centuries ago. Then, if Aceh has assigned the authority to implement Islamic Law for its adherents, this would certainly not be an obstacle and a hurdle for Aceh likely to pass and implement Islamic criminal Law as a whole, including qisas sanctions for capital punishment. Unfortunately, the qanun or article that regulates this matter had not yet been issuing by the Aceh government and DPRA. Although, several Qanun was regulated and ratified, not all the draft of Qanun such as the Qanun Jinayah of Aceh Qanun in term of the legislative process becomes a positive law smoothly due to various structural, substantive and cultural challenges and obstacles. ${ }^{32}$

\footnotetext{
${ }^{30}$ Ibid.

31 Amsori \& Jailani. (2017). Legislasi Qanun Jinayat Aceh Dalam Sistem Hukum Nasional. Ar Raniry: International Journal Of Islamic Studies, 4(2): 221-256.

32 Ibid.
} 
According to Husni Jalil, as quoted by Hani Adhani, says that one of the main obstacles to the implementation of Islamic Law in Aceh is the existence of Law (Indonesian Law) that restricts or limits the authority of the Aceh Government in issuing Qanun or Governor Regulation. He reveals that Qanun must not conflict with the public interest, Regional Regulation / other Qanun, and higher laws and regulations. Furthermore, Husni Jalil refers to the provisions in Law Number 32 of 2004 about the Regional Government. The Law mentions that a Regional Regulation (Qanun) could contain a maximum of six months imprisonment or a maximum fine of Rp.50,000,000 (fifty million Rupiah) with or not seizing certain assets for the region unless stipulated contrarily in another regulation. ${ }^{33}$ In line with that, Law No. 12 of 2011 concerning legislation, article 2 states that Pancasila is all Indonesian law sources. Additionally, in Article 15 paragraph 2, it is affirmed that; the punishment for crimes as referred to the paragraph (1), point $\mathrm{b}$ and $\mathrm{c}$ are with imprisonment for a maximum of 6 (six) months or a maximum fine of Rp 50,000,000 (fifty million Rupiah). Shortly speaking that this provision as known together is not synchronous with the will of the criminal threat contained in the Al-Qur'an and Hadith.

Accordingly, the Fiqh scholars such as Muhammad Abū Zahrah and Abdul Qadir Audah express that jarimah (crimes) is divided into three categories, namely hudūd (crimes of fixed punishment), Qisas and Diyāt (crimes of retaliation and blood money) and $\mathrm{Ta}^{\prime} z \bar{i}$ (crimes of discretionary penalty). There are seven types of Jarimah Hudud, namely, adultery, qadhaf, khamar, sirqah (robbery), hirabah (mugger), riddah (apostasy) and al-baghi (insurrectionist). Whereas Qișas and diyāt are divided into two kinds of crimes; murder and hurts, which reaches the standard of crime that can be punished by Qisas and diyāt. However, $t a ' z \bar{i} r$ is sentencing for crimes that do not reach the requirements of hadd punishment. It is delegated to the judge or chief executive to decide what the punishment by specific criteria shall be, such as imprisonment, social banishment, fines, and so forth. The determinations of crimes are on the judges' discretion rather than what was prescribed in the Qur'an and Hadis. ${ }^{34}$ Therefore, as far as Qanun Jinayah accommodated stoning and whipping is concerned, it would be contrary to the higher laws, namely Law Number 1 of 1946 jo Law Number 73 of 1958 about the Criminal Code (KUHP) as positive Indonesian Law. Thus, the Government can reverse the Qanun / Regional Regulation with a Presidential Regulation or submit a judicial review to the Supreme Court against the Qanun. ${ }^{35}$

Besides, the factor that also influenced the prolong development of Islamic penal Code as far as the legislative process is concerned is the lack of knowledge and experience of DPRA. In other words, Amsori asserts that the Government's decision to formulate the Islamic Law in Aceh dealt with several problems, such as the lack of understanding of the legislators about the process of enactment of Islamic Law ${ }^{36}$ However, Abdullah Saleh argue that it is not considered as obstacle to the process of formalizing the Qanun

\footnotetext{
${ }^{33}$ Adhani, H. (2019). Menakar Konstitusionalitas Syari'at Islam dan Mahkamah Syar'iyah di Provinsi Aceh. Jurnal Konstitusi, 16(3): 606-629.At https://doi.org/10.31078/jk1638.

34 Zahrah, M. A. (1998). Al-Jarìmah wa Al-Uqūbah fi Al-Fiqh al-Islamī (Kairo: Maktabah Al-Madani, 19, and see also Awdah, A. Q. (1998). Al-Tashri' Al-Jināi Al-Islami Muqarranat Bi Al-Qanūn Al-Wadh'i, Juz 1, 14 th Ed, Beirut: Al-Risālah, 40-51.

35 Adhani, H. (2019). Menakar Konstitusionalitas Syari'at Islam dan Mahkamah Syar'iyah di Provinsi Aceh. Jurnal Konstitusi, 16(3): 606-629.At https:// doi.org/10.31078/jk1638.

36 Amsori \& Jailani. (2017). Legislasi Qanun Jinayat Aceh Dalam Sistem Hukum Nasional. Ar Raniry: International Journal Of Islamic Studies, 4(2): 221-256.
} 
Jinayah in Aceh. He asserted that concerning the qanun legislation process in Aceh, this is not only involved at the DPRA stages, but according to him, in this case, there would be a team of experts who would draft the qanun. Later, the draft was delegated to the DPRA for decision. ${ }^{37}$

Also, the legislative process's obstructions emerge from the rejection of some activists or organizations under Human rights. They refused the draft of Qanun jinayah. This Qanun, according to them, allows discrimination against fundamental human rights, primarily if the Qanun related to qisas is issued and enforced in Aceh. ${ }^{38}$ Then, the challenge to implement the Aceh Qanun No 6 of 2014 came from civil society members of the Institute for Criminal Justice Law (ICJR). ICJR proposes testing of this Qanun, and even invites several community organizations and women's solidarity to submit a Judicial Review to Supreme Court. The ICJR encourages that article 235 of Law No. 11 of 2006 about Aceh Government shall be revised. ${ }^{39}$

In addition, the ruling party's influence or interference in some issues led to the process of Aceh criminal legislation often faces obstacles. It is evident with the issuance of Governor Regulation No. 5 of 2018, which revises the whip mechanism, and the caning shall administer in a secure place (Lembaga Pemasyarakatan). In contrast, according to Qanūn Acara Jināyah No. 7 of 2013 (Islamic Criminal Procedural Code), there mentions the caning sentence against an offender, which shall administer in public and open places. The factor of this revision is precisely the interest of the authorities in Aceh at the time for specific reasons. Furthermore, the Governor of Aceh asserted that the openly caning sentences could prevent investors from entering Aceh as the caning is terrible for investors. ${ }^{40}$ Even though, the Governor of Aceh, Irwandi Yusuf (2017-218) asserts that the whip sentence's implementation as outlined in Governor Regulation (Pergub) No 5 of 2018 about the Procedural Islamic Criminal Law, the whipping is not contradicted to the Islamic law code. It is because Pergub only governed the technical implementation of the whip sentence. ${ }^{41}$ However, Tengku Faisal Ali ${ }^{42}$ expresses that "There are two things in the implementation of Islamic Law concerning punishment should be considered. First, ultimately, it becomes a lesson for the perpetrators. Second, it becomes a lesson for others in society if it is sentenced publicly, but if it is executed privately (closed places), it only becomes a lesson for him and not others. Furthermore, he adds that the sentence aims to prevent other people from committing

\footnotetext{
37 Abdullah Saleh is the member of DPRA (People Consultative Assembly of Aceh) appointed and assigned as chairman at the Commission I concerning legislation of Qanun. He was interviewed on 19 July 2017 at his official room.

38 Affan. Dianggap merugikan, Perda Syariat Islam di Aceh diusulkan ditinjau - BBC News Indonesia".

Available online from: https://www.bbc.com/indonesia/indonesia-41714022. Accessed on 2 March, 2020 at 09:PM.

${ }^{39}$ Amsori \& Jailani. (2017). Legislasi Qanun Jinayat Aceh Dalam Sistem Hukum Nasional. Ar Raniry: International Journal Of Islamic Studies, 4(2): 221-256.

40 Analisadayli.com. (2018). "Aceh Minim Investasi, Syariat Islam Disalahkan-AnalisaDaily.com". Available online from: https://analisadaily.com/berita/arsip/2018/4/16/538782/aceh-minim-investasisyariat-islam-disalahkan. Accessed on 2 March, 2020 at 10:00 AM..

41 Pemerintah Aceh | Gubernur. (2018). Pelaksanaan Hukuman Cambuk Terbuka Untuk Umum". Available online from: https://acehprov.go.id/news/read/2018/04/12/5467/gubernur-pelaksanaanhukuman-cambuk-terbuka-untuk-umum.html. Accessed on 2 March, 2020 at 11.00 PM.

42 Teungku Faisal Ali assigned currently as the Vice Chairman II of MPU (Ulama Consultative Assembly) of Aceh. The Ulama Consultative Assembly, after this abbreviated as MPU, is an assembly whose members consist of Muslim scholars and intellectuals who are partners to Aceh Government and DPRA (Law No. 11 of 2016).
} 
crimes. That is why the existing regulation shall keep up and not be afraid of no investors coming to Aceh. ${ }^{43}$

So, the historical position and sociological conditions of the Acehnese towards Islamic values is undoubtedly to strengthen the practice of the community's legal life. Based on that, Law's application becomes operative if the existence of Law and custom of society is considered a community's neediness under legal subject. It means that the application of the Qanun Jinayat in Aceh props a majority support from its population because the majority of the population who live there are Muslim. Therefore, the prosperous legislation of Qanun determined by the legal awareness of the community and legal politics of the country. As a result, the implementation of Islamic Law becomes a living law, so the country appears to protect the Qanun Jinayah. ${ }^{44}$ However, the Acehnese understanding about the legislation of Syari'ah concerning the substance of the Law is still prolonged. In fact, for them, the decisive thing is not only about legislation, but the essential is that the Islamic Law straightforward in the "Serambi Mekkah," and Syaria' $h$ is not merely to be used by political interests. ${ }^{45}$ In short, although the obstructions to the legislative process or arrangements of Criminal Code do not much rely on the understanding of the Acehnese, it affects the implementation of Islamic Criminal Law itself.

Furthermore, Abdul Gani reveals that understanding or awareness of the implementation of Islamic Law is a significant factor in operating the country's rule of law. He then adds that three factors cause the rate of high awareness levels of public trust and low public awareness of the Law today; First, the public society does not understand the concept of Islamic Law properly. Due to not understanding, it influences the awareness level of their practice. The level of violations both against the Law and Islamic sharia, such as the case of khamar, maisir, and khalwat is still high. Secondly, the socialization and counseling of the Aceh qanun concerning sharia is still lacking and not yet optimal, both the community or the bureaucracy. Third, there is no proper role model of an official officer in terms of speech and action, especially in the sphere of Islamic law implementation. ${ }^{46}$

\section{Conclusion}

At least four primary obstacles have been identified that prolonged the legislative process and the enforcement of Qanun Jinayah in Aceh, especially concerning murder offenses or capital punishment. The first obstacle is the existence of Laws (Indonesian laws), such as Law Number 32 of 2004, that restrict or limit the Aceh Government's authority in issuing Qanun or Governor Regulation. Some essential elements of Islamic criminal principles conflict with some provisions embodied in National Criminal Code (KUHP), such as murder and adultery offenses. The punishment for these offenses is capital punishment, namely qisas and rajm which are in conflict with the punishment in

43 Usman, A. Ini Tanggapan Wakil Ketua MPU Aceh Tgk Faisal Ali. Available online from: https://modusaceh.co/news/ini-tanggapan-wakil-ketua-mpu-aceh-tgk-faisal-ali/index.html. Accessed on 2 March, 2020) at 11:00 PM.

${ }^{44}$ Amsori \& Jailani. (2017). Legislasi Qanun Jinayat Aceh Dalam Sistem Hukum Nasional. Ar Raniry: International Journal Of Islamic Studies, 4(2): 221-256.

45 Isa, A. G. (2013). Formalisasi Syari'at Islam di Aceh; Pendekatan Adat, Budaya dan Hukum. Banda Aceh:

Yayasan Pena, p. 276.

46 Ibid. 
the KUHP. The second obstacle is the lack of understanding and experience of the Aceh regional legislators about enacting Islamic Law in DPRA (regional level). It must be acknowledged that the process and format for making Shariah law and Islamic legislation in Aceh are different compared to other regions because of the Islamic nature of the Law in Aceh. There must be a complete, comprehensive, clear, and official Shariah-compliant legislative process for Aceh. Due to the absence of such formal guidance within the Indonesian legal system, it slows down its development. Third, the rejection of Syariah by a few activists, NGOs, and organizations on the pretext of human rights. Lastly, influence or interference of the ruling party in some issues.

The view of the local population regarding the Syariah penal code in Aceh is very clear. They agree and support the implementation and enforcement of Islamic Criminal Law in the region. Opposition and criticism against the Syariah penal code, which comes from NGOs, organizations, and social activists that are not local population, claim that Islamic Law conflicts with human rights and thus restrict Acehnese's freedom and rights. Their narration of human rights is based on secular belief and bias against Islam. Furthermore, this view does not recognize the aspiration of the Acehnese. The local population has a solid attachment to Syariah since time immemorial. Islam is deep-rooted in the history and culture of Aceh. The application and enforcement of Islamic Criminal Law in the region fulfill the local population's need and desire, which has been denied for so long. Therefore, the people's intention to implement the Islamic Law included Islamic criminal Law in Aceh was seen as a pluralism attempt for decades.

\section{References}

\section{Books:}

Abubakar, A-Y. \& Marahalim. (2006). Hukum Pidana Islam di Provinsi Nanggroe Aceh Darussalam. Banda Aceh: Dinas Syari'at Islam.

Abubakar, A-Y. (2019). Syariat Islam di Aceh: Sebagai Keistimewaan dan Otonomi asimetris; Telaah Konsep dan Kewenangan. (Islamic Law in Aceh: As a Special and Asymmetrical Autonomy; An Authoritative and Conceptual Approaches) ed. By Ridwan Nurdin, Aceh: Sahifah.

Affan. Dianggap merugikan, Perda Syariat Islam di Aceh diusulkan ditinjau - BBC News Indonesia". Available online from: https://www.bbc.com/indonesia/indonesia41714022. Accessed on 2 March, 2020 at 09:PM.

Analisadayli.com. (2018). "Aceh Minim Investasi, Syariat Islam DisalahkanAnalisaDaily.com". Available online from: https://analisadaily.com/berita/arsip/2018/4/16/538782/aceh-miniminvestasi-syariat-islam-disalahkan. Accessed on 2 March, 2020 at 10:00 AM.

Aspinall, E. (2005). The Helsinki Agreement: A more promising basis for peace in Aceh? Washington: East-West Center Washington.

Awdah, A. Q. (1998). Al-Tashri' Al-Jināi Al-Islami Muqarranat Bi Al-Qanūn Al-Wadh'i, Juz $1,14^{\text {th }}$ Ed, Beirut: Al-Risālah 
Bassiouni, M. C. (1982). Sources of Islamic Law, and The Protection of Human Rights in The Islamic Criminal Justice System in The Islamic criminal justice system. Ed. Bassiouni, M. The United States of America: Oceana Publications Inc.

David W. N. (1999). America's Courts and the Criminal Justice System. 6th ed, The United States of America: Wadsworth Publishing Company.

Friedman, L. M. (1992), "Legal Culture ." Encyclopedia of the American Constitution, Encyclopedia.com. (accessed on February 24, 2020). Accessed At the

https://www.encyclopedia.com/politics/encyclopedias-almanacs-transcriptsand-maps/legal-culture

Isa, A. G. (2013). Formalisasi Syari'at Islam di Aceh; Pendekatan Adat, Budaya dan Hukum. Banda Aceh: Yayasan Pena.

Lexico Dictionary, accessed at https://www.lexico.com/definition/criminal_justice_system on 20 February of 2020.

Pemerintah Aceh | Gubernur: Pelaksanaan Hukuman Cambuk Terbuka Untuk Umum", <https://acehprov.go.id/news/read/2018/04/12/5467/gubernurpelaksanaan-hukuman-cambuk-terbuka-untuk-umum.html> (accessed 2 March, 2020).

Projowikoro, W. (1985). Asas-asas Hukum Pidana di Indonesia. Cet. 4, (Bandung: PT. Eresco Jakarta.

Projowikoro, W. (1986). Asas-asas Hukum Pidana di Indonesia. Edisi ke-2 dari Cet. Ke-4, Bandung: PT. Eresco Bandung.

Pursley, R. D. (1991). Introduction to Criminal Justice, 5th ed. The United States of America: Macmillan Publishing Company.

Safrijal, A. (2017). Hukum Pidana Islam/Jinayat Dan Pelaksanaannya Di Aceh (Islamic Criminal Law/Jinayat and Its Implementation in Aceh). 1st ed. Banda Aceh: FH UNMUHA.

Senna, J. J. \& Siegel, L. J. (1999). Introduction to Criminal Justice. $8^{\text {th }}$ Edition, The United State of America: Wadsworth Publishing Company.

Tengku Hasan, Jum Meurdehka: Seunurat Njang Gohlom Lheuh Nibak Teungku Hasan di Tiro, Vol. 1, (England: Angkatan Atjeh Meurdehka, 1985), p. i.

Thegurdian, Idonesian province considers beheading as murder punishment | World news | The Guardian", <https://www.theguardian.com/world/2018/mar/14/indonesian-provinceaceh-considers-beheading-as-punishment> (accessed 26 February, 2020).

Usman, A. Ini Tanggapan Wakil Ketua MPU Aceh Tgk Faisal Ali. Available online from: https:// modusaceh.co/news/ini-tanggapan-wakil-ketua-mpu-aceh-tgk-faisalali/index.html. Accessed on 2 March, 2020) at 11:00 PM.

Zahrah, M. A. (1998). Al-Jarìmah wa Al-Uqūbah fi Al-Figh al-Islamì. Kairo: Maktabah AlMadani. 


\section{Journal Articles:}

Abubakar, M, Suhaimi \& Basri. (2011). Kewenangan Pemerintah Aceh terhadap Pelaksanaan Fungsi Mahkamah Syar'iyah dalam Sistem Peradilan Nasional (Tinjauan tentang Kewenangan Yustisi dalam Otonomi Khusus). Kanun: Jurnal Ilmu Hukum, 3(1): 49-64, and see also Ernawati (2014).

Adhani, H. (2019). Menakar Konstitusionalitas Syari'at Islam dan Mahkamah Syar'iyah di Provinsi Aceh. Jurnal Konstitusi, 16(3): 606-629.At https://doi.org/10.31078/jk1638.

Amsori \& Jailani. (2017). Legislasi Qanun Jinayat Aceh Dalam Sistem Hukum Nasional. Ar Raniry: International Journal Of Islamic Studies, 4(2): 221-256.

Bahiej, A. (2014). Studi Komparatif terhadap Qanun Aceh tentang Hukum Jinayat dan Enakmen Jenayah Syariah Selangor Malaysia. Asy-Syir'ah, 48(2): 333-361.

Ernawati. (2014). Kewenangan Mahkamah Syar'iyah Di Aceh Terhadap Hukum Jinayah Keterkaitan Hukum Materiil Dan Hukum Formil. Forum Ilmiah Indonusa, 11(3): 433-445.

Maulana, R.(2019). Sistem Hukum Di Aceh Dan Kaitannya Dengan Pluralisme Hukum. Jurnal Geuthëe: Penelitian Multidisiplin, 2(3): 323-331.

Nurdin, R. (2018). Kedudukan Qanun Jinayat Aceh dalam Sistem Hukum Pidana Nasional Indonesia. MIQOT: Jurnal Ilmu-ilmu Keislaman, 42(2).

Ulfah, E. N. (2016). Urgensi Pembaruan Kitab Undang-Undang Hukum Pidana: Analisis Kajian Perkara Nomor 46/PUU-XIV/2016. IJCLS (Indonesian Journal of Criminal Law Studies), 1(1): 72-86.

\section{Statutes:}

Law No. 11 of 2006

Law No. 18 of 2001

Law No. 44 of 1999

Law No. 73 of 1958

Law No. 12 of 1995

Law No. 1 of 1946

Qanun of Aceh No. 5 of 2000

Qanun of Aceh No. 6 of 2014

Qanun of Aceh No. 7 of 2013

Qanun of Aceh No. 9 of 2008 